\title{
Management accounting and control for sustainability and strategic decision making
}

\author{
Elaine Harris ${ }^{1} \cdot$ Christian Herzig $^{2} \cdot$ Ivo De Loo $^{3} \cdot$ Melina Manochin $^{3}$
}

(c) Springer-Verlag GmbH Germany, part of Springer Nature 2019

Management accounting practice emerges as a highly situated phenomena limited by historical conditions that are specific to given times and places; limited by local meanings and values; limited by the local rationalities found in particular organisational settings; and limited by the individual habitudes of organisational participants who are connected to the conduct of management accounting work (Baxter and Chua 2003, p. 108).

In the past decade, there has been a significant rise in sustainability control systems (SCS) in organizations. SCS are increasingly constructed, implemented and modified by the same professionals who are involved in the creation and modification of management control systems (MCS). Hence, they usually comprise management accountants.

Prior research on sustainability and management accounting and control has focused mainly on the performance effects of SCSs (Searcy 2012). Relatively little attention has hitherto been paid to how these systems came about in organizations; how and why they evolved to have specific content and shape; how they are actually used; and if and how they ultimately get to be integrated with other systems prevailing in an organization-including MCS. The aforementioned citation from Baxter and Chua (2003) has been included to highlight the importance of studying exactly such practices, albeit from an SCS viewpoint. SCS may (or may not) address environmental and social issues in an integrated way along with financially oriented controls. Gond et al. (2012) theorize various forms of system integration and the ways in which they affect the level of sustainability integration within organizations. Generally, there is a view that SCS ought not to be treated as stand-alone systems. Even if not fully integrated as proposed by Thomas and McElroy (2016), they may be acknowledged as part of a management control package (Grabner and Moers 2013; Malmi and Brown 2008).

\footnotetext{
Ivo De Loo

i.de-loo@aston.ac.uk

1 University of Roehampton, London, UK

2 University of Kassel, Kassel, Germany

3 Aston Business School, Birmingham, UK
} 
Organizations are currently constructing narratives to highlight their commitment to and involvement in a variety of sustainability efforts. On paper, these efforts appear to line up well with the strategy organizations purport to follow. An interesting question is how far such efforts are actually aligned with organizational strategies in practice, and how far they are reflected in the SCS and/or MCS organizations use. SCS and MCS aim to monitor and steer an organization's functioning and decision-making processes, including those relating to sustainability issues. They also typically aim to influence people's behaviors (Berry et al. 2005). But: how far is this really the case? How far is what organizations say they do 'on the tin' aligned with how they run their business and their daily affairs when it comes to SCS?

In order to explore these questions, this special issue comprises a collection of four papers that contribute to the SCS debate. These contributions include papers developed from those presented at the MARG/MCA conference at Aston, Birmingham, UK in November 2017.

The first paper by Biswaraj Ghosh, Christian Herzig and Musa Mangena reviews research investigating the relationship between management control and sustainability strategy. It reveals a range of controls for sustainability strategies. In particular, the review shows that both formal and informal controls have significant roles to play in strategizing sustainability. However, disparities exist within the literature with regard to congruity or primacy of formal and informal controls, indicating a need for further research exploring the relationship of these types of controls. Gosh et al.'s review also shows that studies have been equally interested in both narrow specifications of management control for sustainability (e.g., limiting controls exclusively to individual accounting based controls) and broader conceptualizations of control. The latter stream of research enhances our understanding of the relevance of a multiplicity of controls to manage sustainability. More generally, Ghosh et al. show that previous studies into controls for sustainability are predominantly conceptualized from a control design and strategy process perspective (with a strong focus on strategy implementation). This gives ample space for future research exploring more explicitly how controls are actually used within organizations (for both implementing and formulating sustainability strategies); how the type, nature, relevance and evidence given to a set of controls are informed by difference strategic orientations; and what role controls could play in strategic progression (Gond et al. 2012). In this regard, Gosh et al.'s observation somewhat echoes Neugebauer et al.'s (2015) concerns that researchers have largely ignored the diverse viewpoints that exist on strategies and processes of strategizing, as the debate has been governed by different schools of thought assuming strategy to be an outcome of a rational and planned process (Ansoff 1987; Riccaboni and Leone 2010). As argued by Neugebauer et al. (2015), sustainability should be considered to be a complex and wicked issue (Frame 2008) as well. A planned process may not necessarily reflect a genuine attempt to solve those issues, particularly those wicked issues that are not easily controllable. Related to this, Gosh et al. encourage future research to: (1) consider more strongly the perspective of employees and middle managers when examining the role and use of controls for sustainability strategies (as, for example, is done by Grubnic et al. (2015); (2) overcome the dominant focus on large to very large companies in such 
research; and (3) explore the two-way relationship between sustainability strategy and management controls (this is sometimes called the "strategy-control lifecycle").

The second paper by Leanne Johnstone explores the development process of SCS and the relationship between system design (control over) and use by individuals (control in situ) of control systems in a conceptual paper that builds on the framework proposed by Adler and Borys (1996). Based on a systematic literature review, Johnstone suggests that the more the notion of individual employees exercising agency in an organisational context is incorporated into SCS design, the more effective the control system is likely to be, leading to better sustainability outcomes. She also argues that individual organisational members and their values and beliefs should be placed at the centre of future SCS research as it is by their actions that sustainable performance is achieved. This paper, among others, offers a critique of Simons' (1995) levers of control framework, where the role of individuals, especially non-managerial employees is seen as having been underplayed. Other theoretical concepts are explored, including boundary spanners (Breunig and Roberts 2013) as being especially applicable in relation to sustainability performance. Johnstone makes a case for SCS design to acknowledge the multiple extra-organisational influences on employees' behaviour and place more emphasis upon individual competences for sustainable development. She encourages future SCS researchers to investigate organisational actors' perspectives beyond the typical managerial tiers to extend our knowledge of control as a social practice.

Volker Lingnau, Florian Fuchs and Florian Beham investigate in the third paper whether consumer behaviour is influenced by an organisation's uptake of sustainability practices. The study puts forward a number of hypothesis that relate company sustainability practices with the willingness of consumer's to pay for a product based on their perception of the adequacy of those practices. The results indicate that consumers are more likely to be alerted by indications of unsustainable conduct of coffee producers rather than simply by a sustainability certification in place. The findings of the study have a wide-ranging impact as organizational decisions regarding costumer profitability analysis or other strategic management accounting techniques may become better informed when considering consumers' appetite for indications of ethical organizational behaviour.

Finally, Madeleine Feder and Barbara Weißenberger examine, using the theory of planned behaviour, how top-level managers feel about engaging in CSR-related activities given the potential management control problems that might occur when they do this, which might deviate substantially from corporate expectations. Two online surveys among top-level managers in a range of German firms suggest that managers who are willing to engage in such activities will often do so when they feel sufficiently supported. We believe this study may have important implications for the design of effective management control systems in line with corporate CSRrelated goals and strategic objectives. 


\section{References}

Adler, P. S., \& Borys, B. (1996). Two types of bureaucracy: Enabling and coercive. Administrative Science Quarterly, 41(1), 61-89.

Ansoff, H. I. (1987). The emerging paradigm of strategic behavior. Strategic Management Journal, 8(6), $501-515$.

Baxter, J., \& Chua, W. F. (2003). Alternative management accounting research-Whence and whither. Accounting, Organizations and Society, 28(2/3), 97-126.

Berry, A. J., Broadbent, J., \& Otley, D. (2005). Approaches to control in the organizational literature. In A. J. Berry, J. Broadbent, \& D. Otley (Eds.), Management control: Theories, issues and performance (2nd ed., pp. 17-28). Basingstoke: Palgrave Macmillan.

Breunig, K. J., \& Roberts, H. (2013). Caught off balance: Managing knowledge value creation through boundary spanning roles. International Journal of Learning and Intellectual Capital, 10(3-4), 258-275.

Frame, B. (2008). 'Wicked', 'messy', and 'clumsy': Long-term frameworks for sustainability. Environment and Planning C: Government and Policy, 26(6), 1113-1128.

Gond, J.-P., Grubnic, S., Herzig, C., \& Moon, J. (2012). Configuring management control systems: Theorizing the integration of strategy and sustainability. Management Accounting Research, 23(3), 205-223.

Grabner, I., \& Moers, F. (2013). Management control as a system or a package? Conceptual and empirical issues. Accounting, Organizations and Society, 38(6), 407-419.

Grubnic, S., Herzig, C., Gond, J. P., \& Moon, J. (2015). A new era-Extending environmental impact to a broader sustainability agenda: The case of commercial group. Social and Environmental Accountability Journal, 35(3), 176-193.

Malmi, T., \& Brown, D. A. (2008). Management control systems as a package-Opportunities, challenges and research directions. Management Accounting Research, 19(4), 287-300.

Neugebauer, F., Figge, F., \& Hahn, T. (2015). Planned or emergent strategy making? Exploring the formation of corporate sustainability strategies. Business Strategy and the Environment, 25, 323-336.

Riccaboni, A., \& Leone, E. (2010). Implementing strategies through management control systems: The case of sustainability. International Journal of Productivity and Performance Management, 59(2), 130-144.

Searcy, C. (2012). Corporate sustainability performance measurement systems: A review and research agenda. Journal of Business Ethics, 107(3), 239-253.

Simons, R. (1995). Levers of control: How managers use innovative control systems to drive strategic renewal. Boston: Harvard Business School Press.

Thomas, M. P., \& McElroy, M. W. (2016). The MultiCapital scorecard: Rethinking organizational performance. Vermont: Chelsea Green Publishing.

Publisher's Note Springer Nature remains neutral with regard to jurisdictional claims in published maps and institutional affiliations. 